\title{
Intellectual Freedom in Academic Libraries: Surveying Deans about Its Significance
}

\author{
Shannon M. Oltmann
}

\begin{abstract}
In this study, deans and directors of academic libraries were surveyed about intellectual freedom. The survey found that most respondents said they rarely think about intellectual freedom yet said it was "somewhat" or "very" important in their libraries. Most did not have formal intellectual freedom policies; they often relied on statements from the American Library Association or other library organizations. Copyright/intellectual property, privacy, plagiarism, and academic freedom were the most important concerns related to intellectual freedom. Although this study shed some light on intellectual freedom in academic libraries, further work remains to be done.
\end{abstract}

\section{Introduction}

As defined by the American Library Association (ALA), intellectual freedom is "the right of every individual to both seek and receive information from all points of view without restriction. It provides for free access to all expressions of ideas through which any and all sides of a question, cause or movement may be explored." ${ }^{1}$ Compared to public and school libraries, less is known about intellectual freedom in academic libraries.

Ronald Bukoff examined incidents of censorship in a representative sample of small colleges and universities and reported that nearly one-third of the institutions had experienced censorship. ${ }^{2}$ However, his study included cases where a patron raised a complaint, it was discussed, and no further action was taken; these informal complaints (as opposed to formal complaints with paperwork and a formal procedure) are generally not counted as censorship. Dave Harmeyer found some evidence of bias in the collections of California academic libraries, indicating that there may be self-censorship occurring during collection development. ${ }^{3}$ Aside from these two studies, both more than 20 years old, relatively little work has been done on intellectual freedom in academic libraries.

Often, intellectual freedom is thought of as a public or school library concern, not that important to academic libraries. ${ }^{4}$ The common argument is that "the library's profession's intellectual freedom initiatives are not as vital to academic libraries." ${ }^{5}$

To demonstrate the centrality of intellectual freedom for academic libraries, the Association of College and Research Libraries (ACRL) and the American Library As-

Shannon M. Oltmann is an Assistant Professor in the School of Information Science at the University of Kentucky; e-mail: shannon.oltmann@uky.edu. (2017 Shannon M. Oltmann, Attribution-NonCommercial (http://creativecommons.org/licenses/by-nc/4.0/) CC BY-NC. 
sociation (ALA) developed "Intellectual Freedom Principles for Academic Libraries: An Interpretation of the Library Bill of Rights" ${ }^{\prime \prime}$ (see appendix A). These principles articulate the application of intellectual freedom specifically to an academic library context. As noted in the preamble, "a strong intellectual freedom perspective is critical to the development of academic library collections and services." ${ }^{7}$ Likewise, in his editorial as the president of the Association of College and Research Libraries (ACRL), W. Lee Hisle (1998) argued that "intellectual freedom is a clear bedrock of our value system."

The literature about intellectual freedom in academic libraries is sparse, but there are three common strands: a relationship between academic freedom and intellectual freedom, the finding that academic libraries face fewer censorship challenges than public or school libraries, and the study of several specific topics related to intellectual freedom, such as Internet filtering and privacy of patron records.

First, there is a relationship between intellectual freedom and academic freedom. According to Richard Danner and Barbara Bintliff, academic freedom can be defined as "the atmosphere of free inquiry and discussion necessary to find and teach 'truth' as the faculty member sees it." ${ }^{\prime 9}$ Barbara Jones notes that academic freedom and intellectual freedom have the same roots, originating from a belief in the right to free expression and access to expression. ${ }^{10}$ However, intellectual freedom, as generally conceived by librarianship, tends to focus on access to different ideas, whereas academic freedom tends to focus on expression. ${ }^{11}$ In addition, academic freedom is seen as a privilege (rather than a right), granted by an institution of higher learning to facilitate teaching and research. ${ }^{12}$ The literature suggests that many academic librarians (those who have tenure and faculty status) have the privilege and protection of academic freedom. ${ }^{13}$

Second, several scholars note that academic libraries face fewer censorship challenges than public or school libraries do. For example, Jones notes that "academic libraries are not usually affected as much by traditional censorship as public libraries are."14 Thus, according to the literature, most academic libraries do not face challenges to remove items or restrict access. ${ }^{15}$ In part, this is because faculty and college or university administrators generally recognize that a wide variety of views needs to be present in the institution's library because "research and teaching depend on an environment supportive of academic freedom." 16

Third, several issues connected to intellectual freedom are important in academic libraries (even if the central theme of intellectual freedom itself is not always emphasized). J. Douglas Archer, for instance, notes that the shift to electronic-only resources, concurrent with a shift from owning materials to leasing access, is a significant intellectual freedom concern. ${ }^{17}$ The fixedness of materials as well as continuing access may be in question. Another issue, related to intellectual freedom, is privacy of student information. The privacy of student records is a frequent concern in academic libraries, especially in light of licensing contracts. ${ }^{18}$ Jones notes that there may be some conflict in the intellectual property realm, between providing access to patrons and protecting the rights of those who created the information..$^{19}$ Jones agrees with Danner and Bintliff that Internet filtering should not be an issue in academic libraries, because there are usually no minors present and because patrons need unfiltered access to study a wide range of perspectives. ${ }^{20}$ Another issue, related to intellectual freedom, is collection development; scholars note that collection development in academic libraries "embraces the principles of intellectual freedom in every decision to purchase or share library information resources." ${ }^{21}$ Related to these issues, Jones emphasizes the need for written policies to clarify the library's responsibilities and patrons' rights.

Based on her research, Jones suggests that many academic libraries have not adopted

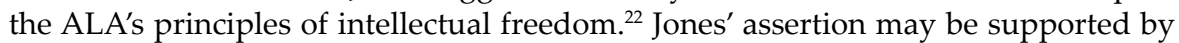
the relative paucity of relevant research; perhaps there is little research because it is an 
unimportant area for academic libraries. This project is an initial attempt to learn about intellectual freedom issues in academic libraries and how they are being addressed.

\section{Methods}

To determine more about academic librarians' perspectives on intellectual freedom, a survey was developed in the fall of 2015 using Qualtrics software. A list of academic library deans and directors was compiled by student workers; they began with the Data Files of Academic Libraries from the National Center for Education Statistics (2012 edition) and then found the dean/director e-mail addresses on the academic library websites. In this manner, 2,668 e-mail addresses were compiled. Each individual was then sent a brief explanatory letter and a link to the survey via e-mail. The survey took approximately 15-25 minutes to complete and was a mixture of multiple-choice and open-ended questions. The Qualtrics software records answers and, as with this survey, can be set up to not record IP addresses, thus ensuring anonymity for respondents. From the 2,668 potential respondents, 512 completed the survey, for a response rate of $19.2 \%$.

\section{Results}

\section{Basic Demographic Information}

Respondents were asked about their institutional profile as well as some demographic questions. First, they were asked about the Carnegie classification (http://carnegieclassifications.iu.edu/) of their institution (see table 1). The most common responses were from associate colleges (29.2\%) and baccalaureate colleges (27.8\%). Research institutions with doctoral programs (R1, R2, and R3 institutions) totaled 11 percent of the sample and M1 and M2 universities totaled 17.6 percent. Approximately 7 percent of the respondents were unsure how to classify their institution and 7.4 percent chose "other" as their classification. For the subsequent analysis, institutions with doctoral and masters programs will be combined into one category (research universities), to be compared with baccalaureate and associate colleges.

Respondents were also asked if their institutions were historically black colleges or universities (HBCU). However, only 1.61 percent $(n=8)$ identified as such, with 97.59 percent $(n=486)$ answering negatively. In addition, respondents were asked if their library was combined with a public or K-12 library; in some rural or underserved areas, libraries may combine to make the best use of limited resources. This may have an impact on how intellectual freedom is understood and applied. Only 2.41 percent $(n=12)$ respondents answered yes, with 97.59 percent $(n=486)$ answering no to this question. Thus, it is unlikely that there will be identifiable variance based on either HBCU status or combination with another type of library.

In addition to information about their institutions, respondents were also asked for some basic demographic information about themselves. Two thirds of respondents were women $(66.27 \%, \mathrm{n}=330)$, one third were men $(31.33 \%, n=156)$, and 2.41 percent $(n=12)$ responded "other/prefer not to answer." While senior administrative positions were once dominated disproportion-

\begin{tabular}{|l|c|c|}
\hline \multicolumn{3}{|c|}{$\begin{array}{c}\text { TABLE 1 } \\
\text { Carnegie Classifications of } \\
\text { Respondents' Institutions }\end{array}$} \\
\hline \multicolumn{1}{|c|}{ Classification } & Number & Percent \\
\hline R1 university & 29 & 5.80 \\
\hline R2 university & 13 & 2.60 \\
\hline R3 university & 13 & 2.60 \\
\hline M1 university & 45 & 9.00 \\
\hline M2 university & 43 & 8.60 \\
\hline Baccalaureate college & 139 & 27.80 \\
\hline Associate college & 146 & 29.20 \\
\hline Other & 37 & 7.40 \\
\hline Not sure & 35 & 7.00 \\
\hline
\end{tabular}


ately by men, ${ }^{23}$ these results suggest that the situation may be changing.

Most respondents $(53.00 \%, \mathrm{n}=265)$ were over the age of 55 (see table 2). The next largest category was ages 46-55 (22.8\%, n=114). Approximately 20 percent $(n=104)$ of respondents were 45 years old or younger. These data support anecdotal evidence that many library administrators are at or near retirement age (the so-called "graying" of the profession). ${ }^{24}$

\begin{tabular}{|l|c|c|}
\hline \multicolumn{3}{|c|}{ TABLE 2} \\
Age of Respondents \\
\hline \multicolumn{1}{|c|}{ Age Category } & Number & Percent \\
\hline 25 or younger & 1 & 0.2 \\
\hline $26-35$ & 34 & 6.8 \\
\hline $36-45$ & 69 & 13.8 \\
\hline $46-55$ & 114 & 22.8 \\
\hline 56 or older & 265 & 53.0 \\
\hline Prefer not to answer & 17 & 3.4 \\
\hline
\end{tabular}

\begin{tabular}{|l|c|c|}
\hline \multicolumn{3}{|c|}{ TABLE 3 } \\
Degrees Held by Respondents \\
\hline \multicolumn{1}{|c|}{ Degree } & Number & Percent \\
\hline MLS or equivalent & 459 & 91.8 \\
\hline Other Master's degree & 178 & 35.6 \\
\hline Ph.D. or equivalent & 68 & 13.6 \\
\hline J.D. & 7 & 1.4 \\
\hline None of the above & 2 & 0.4 \\
\hline Other & 20 & 4.0 \\
\hline
\end{tabular}

Finally, respondents were asked about their educational background (see table 3 ). The overwhelming majority of respondents $(91.80 \%, \mathrm{n}=459)$ had a MLS or equivalent degree. Just over one-third of respondents $(35.60 \%, n=178)$ had a second master's degree, while only 13.60 percent $(n=68)$ had a doctorate. Respondents were allowed to write in additional responses; several indicated they held a bachelor's degree; other said they were completing a MLS or equivalent degree or a doctoral degree. Two reported they held associate degrees.

\section{Intellectual Freedom Policies and Training}

To investigate the extent to which intellectual freedom is formally incorporated in academic libraries, respondents were asked about their written policies. Just over half of respondents $(52.79 \%, \mathrm{n}=246)$ indicated that their library did not have a formal intellectual freedom policy, while 43.78 percent $(n=204)$ reported that they did have an intellectual freedom policy, and 3.43 percent $(n=16)$ were unsure. There was no significant difference among research, baccalaureate, and associate colleges $\left(x^{2}(2)=2.46, P=0.2926\right)$ with regard to whether they had a formal intellectual freedom policy. However, more than half of the respondents reported that intellectual freedom was included in their collection development policies: 53.22 percent $(n=248)$ said intellectual freedom was referred to in their collection development policies (with $40.56 \%$ [ $n=189$ ] disagreeing and $6.22 \%$ [n=29] unsure). Thus, it appears that some academic libraries have separate, distinct intellectual freedom policies, while others prefer to incorporate intellectual freedom as part of collection development; of course, there may be a good deal of overlap in these categories as well. Again, there was no significant difference among research, baccalaureate, and associate colleges $\left(x^{2}(2)=0.78, P=0.6760\right)$.

In addition to the formal presence of intellectual freedom, respondents were asked about the use of core documents from the American Library Association. Such documents, including the Library Bill of Rights and the Code of Ethics, form a foundation of ethical principles for the profession, and intellectual freedom is strongly encoded into these documents. As demonstrated in table 4, only a few guiding documents from the ALA were used in respondents' libraries. 


\begin{tabular}{|l|c|c|}
\hline \multicolumn{3}{|c|}{ TABLE 4 } \\
\hline \multicolumn{2}{|c|}{ Use of Guiding Documents from the ALA } \\
\hline Document & Number & Percent \\
\hline Library Bill of Rights & 294 & 64.62 \\
\hline Code of Ethics & 228 & 50.11 \\
\hline Intellectual Freedom Principles for Academic Libraries & 149 & 32.75 \\
\hline Freedom to Read Statement & 143 & 31.43 \\
\hline Core Values of Librarianship & 96 & 21.10 \\
\hline Freedom to View Statement & 56 & 12.31 \\
\hline None of the above & 99 & 21.76 \\
\hline Other & 22 & 4.84 \\
\hline
\end{tabular}

The Library Bill of Rights was the most frequently used document, with nearly two-thirds of respondents $(64.62 \%, \mathrm{n}=294)$ indicating it was referred to or used by their library, followed by the Code of Ethics $(50.11 \%, n=228)$. Both the Intellectual Freedom Principles for Academic Libraries and the Freedom to Read Statement were used by nearly one-third of libraries (32.75\% [ $n=149]$ and $31.43 \%$ [ $n=143]$, respectively). Somewhat surprisingly, more than one-fifth $(21.76 \%, \mathrm{n}=99)$ of respondents indicated that their library's policies did not refer to any of the listed documents. For the "other" documents, responses included standards from the Association of Theological Schools and the Medical Library Association Code of Ethics; the most common response was ACRL standards (particularly the Diversity Standards) and referral to university-level policies. For example, one respondent reported an "institutional commitment to open inquiry," and another said simply, "the campus has a policy."

However, other respondents indicated their policies were less formal. One noted, "We might refer to any of these if an issue or a reason ever came up but these aren't in our policy documents." Another said, "We are a very small library and we don't have it all in writing but we do put these into practice." A third respondent explained that the library didn't formally refer to any of these policies or documents but "individual librarians consider individual issues."

On a related topic, the survey also asked respondents about whether their library provided formal employee training in intellectual freedom. As with the formal inclusion of intellectual freedom topics in policy documents, formal intellectual freedom training is a sign that the library is serious in its commitment to intellectual freedom. For this reason, respondents were asked whether they provide "intellectual freedom training" to their staff (the meaning of this phrase was left up to the respondents). Some indicated that most of their staff were student workers, who had little responsibility and high turnover, so intellectual freedom training may not be particularly useful for them. Others indicated that their staff was very small (sometimes just one person, the respondent) so formal training was not an option or a priority. However, responses generally fell into three categories: no current training, but interested in such; some informal training and discussion; and some level of formal training and discussion.

For the first group (totaling 11), one respondent is representative: “We do not, but this question makes me wish we did. This is something we will look into providing in the near future." Similarly, another librarian said, "We've not found a need for formal training but should probably consider it as a matter of professionalism." A third commented, "Not currently, but am very open to doing so." Most of these respondents 
had not considered offering training in intellectual freedom but, once asked about it, acknowledged the value it could offer.

Twenty-one respondents indicated that their library offered some informal training, generally discussions during staff meetings. For example, one said, "No formal training is given, but often discussions concerning intellectual freedom do come up and the policy is always referred to." Often, these conversations span several years and are part of the ongoing discussion about how to interpret and apply policy. A librarian noted, "We don't provide dedicated, formal training but we discuss it frequently and it is part of our core values." One respondent said, "When issues come up, we address them...the other day, one of my newer staff people wanted to put out books that exclusively supported her specific candidate. We discussed intellectual freedom, choice, and censorship and I think she came away better informed." Some respondents indicated some hesitation with this approach. For example, one librarian said, "We just mention it and sort of assume since they work at a liberal arts college that they know. The idea of intellectual freedom is embedded everywhere in the campus." Finally, one librarian reported discussing intellectual freedom with the staff, "just enough that it disturbs their original thinking."

The third group of responses to this question (with 31 respondents) indicated that several libraries do offer formal training about intellectual freedom. Often, this is directed at new employees and/or student workers, those who may not have been exposed to intellectual freedom values through MLS education. One respondent explained, "In addition to being made familiar with ALA and institutional policies, all staff participate in ongoing professional development activities." Another offered a detailed description of the institution's training: "Most of our professional development comes from training offered through the Louisiana Library Association, the American Library Association, and the Association of College and Research Libraries. We have also participated in training through our yearly system office convention and through the consortium. These have been showcased as one shot workshops, talks and discussions and workbook classes with discussions." Others are equally engaged in intellectual freedom training; one noted that "we actively promote this during Banned Books Week, library events, Privacy Week, and in our conversations on campus committees." Some respondents acknowledged that intellectual freedom can be an encompassing phrase, noting "we address it in terms of training on copyright, open access and privacy." Another librarian noted, "The training we do related to intellectual freedom is focused on how to respond if library users object to content that other library users are viewing or reading."

\section{Importance of Intellectual Freedom}

While the importance of intellectual freedom may be readily acknowledged in public and school libraries, as mentioned above, its significance and value in academic libraries is not as clear. Respondents were asked how often they think about intellectual freedom, in their role as academic library directors or deans, to try to gauge its overall importance.

As table 5 shows, there was a variety of responses to this question. The most common response was "less than once a month" (23.54\%, n=105), indicating that these academic library directors and deans do not view intellectual freedom as a pressing concern. It is only occasionally on their minds. On the other hand, 40.81 percent of respondents reported thinking about intellectual freedom at least once per week (12.56\% daily, $15.47 \%$ 2-3 times per week, and $12.78 \%$ once per week). For these respondents, intellectual freedom is somewhat more pressing, more commonly a consideration. There was significant variation among research, baccalaureate, and associate institutions $\left(x^{2}(2)=29.46, P=0.0011\right)$. Respondents from research universities were more likely to 


\begin{tabular}{|l|c|c|}
\hline \multicolumn{3}{|c|}{ TABLE 5 } \\
How Often Respondents Think about Intellectual Freedom \\
\hline \multicolumn{1}{|c|}{ Frequency } & Number & Percent \\
\hline Daily & 56 & 12.56 \\
\hline 2-3 times per week & 69 & 15.47 \\
\hline Once a week & 57 & 12.78 \\
\hline 2-3 times per month & 81 & 18.16 \\
\hline Once a month & 71 & 15.92 \\
\hline Less than once a month & 105 & 23.54 \\
\hline Never & 7 & 1.57 \\
\hline
\end{tabular}

think about intellectual freedom rarely (2-3 times a month or once a month) than respondents from baccalaureate or associate colleges.

The above answers are particularly interesting when compared with a related question: respondents were asked "how important is intellectual freedom in your library?" (See table 6.) More than half of the respondents $(58.41 \%, n=264)$ said it was very important, with another 26.99 percent $(n=122)$ saying intellectual freedom was somewhat important. Only 2.66 percent $(n=12)$ said it was somewhat or very unimportant. This seems to indicate that the concept is important in a generalized sense; but, in light of the above, it is not often an urgent, pressing matter for the respondents. There was significant variation among research, baccalaureate, and associate colleges for this question $\left(x^{2}(2)=8.70, P=0.0689\right)$. Respondents from associate colleges were more likely to say intellectual freedom was unimportant at their library, and respondents from research universities were more likely to say intellectual freedom was important.

Respondents could leave additional comments about the importance of intellectual freedom in their libraries, and 62 people did so. Answers fell into four categories: some respondents said intellectual freedom was something they thought about rarely; some said it was a "given" within the academic library environment, some explicitly advocated for intellectual freedom, and some acknowledged difficulties in fulfilling the ideals of intellectual freedom.

As an example of the first category, one respondent said, "To be honest, I really haven't thought about the issue here. I'm the only library staff member and I would never try to hinder a student's access to information." Another explained, "We are a small library at a four-year private college that does not require published research of its faculty or librarians. So intellectual freedom is not really an issue for us." One re-

\begin{tabular}{|c|c|c|}
\hline \multicolumn{3}{|c|}{$\begin{array}{c}\text { TABLE } 6 \\
\text { The Importance of Intellectual Freedom in } \\
\text { Respondents' Libraries }\end{array}$} \\
\hline How Important & Number & Percent \\
\hline Very important & 264 & 58.41 \\
\hline Somewhat important & 122 & 26.99 \\
\hline Neither important or unimportant & 54 & 11.95 \\
\hline Somewhat unimportant & 7 & 1.55 \\
\hline Very unimportant & 5 & 1.11 \\
\hline
\end{tabular}

spondent noted that at his or her community college, students did not have high reading or writing skills and intellectual freedom did not seem important to them; others, at technical or professional schools, voiced similar comments. Each of these respondents seemed to view intellectual freedom somewhat 
narrowly - or, they viewed their community narrowly and did not see how intellectual freedom applied in their context.

In commenting on this topic, many respondents in the second category explained that "it is so important that it's a given, so there's no mention." A second person said, "It's very important because it is at the core of what we do. But ordinarily, it is not something that has much budget or takes much staff attention," while a third simply said, "it is implicit rather than explicit." Here, we see several academic library directors and deans taking intellectual freedom for granted. It's seen as a central principle for their library, but they do not spend a great deal of time or resources on it. One said, "Although we don't have a written policy (yet), this is an issue that is dear to us," meaning the library employees. Similarly, another respondent said, "I think we take it for granted as a shared value. We would defend it if it appeared under threat or question; otherwise we assume it's a shared value at our college." One person added, “Because we don't focus on it doesn't mean that it isn't important. It is an assumption that underlies our work more than something we think about intentionally on a regular basis." Finally, a respondent summarized this view by saying, "[I] don't really think about it when helping students - just part of the DNA of a library to treat all users and questions the same." For these respondents, intellectual freedom was integral to their work at academic libraries - so integral, in fact, that it wasn't something they had to frequently stop and consider.

A third group of respondents were more unequivocal in their discussion about intellectual freedom. One said, "As a school of art and design, intellectual freedom is a value held dear and actively practiced by faculty, students, and staff." A different director said, "We support the right to free inquiry and do not restrict what patrons use or view," while another one said, "It's at the core of our decisions about the collection: both what to add and what to weed." Another one explained:

We feel like this is central to an educational process that encourages the pursuit of truth and the exploration of ideas... We have it built into our Vision, Mission, and Objectives, we try to collect materials that reflect a broad spectrum of views while still maintaining high academic standards.

Other respondents noted Banned Books Week, such as the respondent who said, “To me, intellectual freedom is very important as it reinforces our constitutional rights. It is why I LOVE and promote banned books week."

Finally, there was a group of respondents who indicated some difficulty in thinking about and implementing intellectual freedom at their library. In general, most of these respondents indicated there were some conflicts between the institutional mission (of the university) and the intellectual freedom orientation of the academic library. For example, one said, "It is interesting that there is a bit of disagreement on our staff on how 'intellectually free' we should be since we are a religiously connected university. But we are also a 'liberal arts' university - hence the discord." Similarly, another said, "intellectual freedom within our library collection development policy is limited by the university's religious mission and foundational guidelines." However, some respondents did not let their university's stance determine their approach to intellectual freedom: "The institution I work at is a private Catholic college. Contraception, abortion, the death penalty, [and] other red button issues do come up and when they do, I do not hesitate to acquire the material that the students need."

Respondents were also asked about common principles and concerns that are related to intellectual freedom (see table 7). Copyright and intellectual property were the most common concerns, with more than 90 percent of respondents in- 


\begin{tabular}{|c|c|c|}
\hline \multicolumn{3}{|c|}{$\begin{array}{c}\text { TABLE } 7 \\
\text { Areas of Concern Related to Intellectual } \\
\text { Freedom }\end{array}$} \\
\hline Topic of Concern & Number & Percent \\
\hline Copyright/intellectual property & 416 & 92.04 \\
\hline Plagiarism & 363 & 80.31 \\
\hline Privacy/confidentiality & 333 & 73.67 \\
\hline Academic freedom & 268 & 59.29 \\
\hline Censorship & 180 & 39.82 \\
\hline Internet filtering & 91 & 20.13 \\
\hline Meeting rooms/exhibit spaces & 68 & 15.04 \\
\hline Visits from law enforcement & 31 & 6.86 \\
\hline Other & 18 & 3.98 \\
\hline RFID tags & 10 & 2.21 \\
\hline None of the above & 3 & 0.66 \\
\hline
\end{tabular}

dicating this. Plagiarism and privacy/confidentiality were the next most common concerns $(80.31 \%$ and $73.67 \%$, respectively). The only other concern held by over half of the respondents was academic freedom (59.29\%). Concerns such as censorship, Internet filtering, meeting rooms/exhibit spaces, law enforcement visits, and RFID tags were held by fewer than half of the respondents. However, it is interesting that approximately one-fifth $(20.13 \%)$ reported concern about Internet filtering, since it is not legally mandated at the collegiate level. For most of these concerns, there was no statistical difference among research, baccalaureate, and associate colleges. The exception is with Internet filtering: respondents from associate colleges were more likely to indicate that Internet filtering was a concern for them $\left(x^{2}(2)=6.24, P=0.0441\right)$.

Eighteen respondents indicated "other" concerns. These include records retention policies, computer use policies, freedom of collection development, academic integrity, and security cameras. One respondent indicated concern about "culturally sensitive material-material that should have never been published about Native American tribes - how do we provide access to it while protecting communities[?]" Another respondent noted that intellectual freedom does not exist in isolation: "How often are you aware of your breathing? IF [intellectual freedom] does not exist in a vacuum: it is intertwined with other issues."

\section{Challenges to Intellectual Freedom}

The respondents were asked how often they receive challenges to library materials (see table 8 ). The most frequent response was "never" $(46.68 \%)$, followed by "almost never" $(46.46 \%)$. From this, we can see that most academic libraries do not face challenges to their materials. Those reporting some challenges (between once a week to once a year) total 5.08 percent. There was no significant difference among research, baccalaureate, and associate institutions for this question $\left(x^{2}(2)=3.87, P=0.1444\right)$. This strongly echoes the American Library

Association's statement that most challenges occur in public and school libraries.

TABLE 8

Frequency of Challenges in Academic Libraries

\begin{tabular}{|l|c|c|}
\hline \multicolumn{1}{|c|}{ Frequency } & Number & Percent \\
\hline Once a week & 1 & 0.22 \\
\hline Once a month & 0 & 0.00 \\
\hline 2-3 times per semester & 3 & 0.66 \\
\hline 2-3 times per year & 8 & 1.77 \\
\hline Once a year & 11 & 2.43 \\
\hline Almost never & 210 & 46.46 \\
\hline Never & 211 & 46.68 \\
\hline Not sure & 8 & 1.77 \\
\hline
\end{tabular}


Respondents indicated a number of approaches to handling challenges. Most said that they follow their formal written policy, which calls for a review committee; in addition, most respondents indicated that they use or follow ALA policies as relevant when addressing challenges. For example, one respondent said, "We have a written policy that spells out the process a challenger should follow if he chooses to proceed with the complaint." The process is often fairly similar across libraries; one person reported having a "form for complainant to complete, committee to review complaint and recommend action, meeting of committee and complainant, recommended action forwarded to director, decision of action by director, complainant informed of decision/action and appeals process." Others noted that university or college administrators would get involved in the process, including the provost, a dean, faculty, legal counsel, vice president, or president or a college-level committee.

Several respondents noted they had never had a challenge, which may be why many did not have formal policies in place. One explained, "We're an academic research library and don't get challenged or at least have not in my tenure." Others indicated that they would not seriously consider a challenge to their collection; for example, a respondent said that the staff would "explain to [the challenger] that academic libraries have a duty to make available resources representing a wide variety of opinions and forms of expression." Another added, "The collection is tailored for the faculty and students, so a challenge would not be successful." A third commented, "[the] director crafts a thoughtful response, but materials are never removed from the collection." One respondent was even more direct: "What I say goes. It's my library."

Others provided more nuanced, complex answers. A respondent said, "We have freedom to decide, whether to withdraw the item or leave it in the collection, but sometimes we get pressured to withdraw it." A second respondent said, "We don't have a written policy, but if we were to have a challenge, I would keep the challenged material in the library and add something that would better represent the views of the person challenging." Finally, a director noted, "Because we are a tribal college, we are highly sensitive to bias of all kinds in library materials." It is unclear if this heightened sensitivity leads to more challenges, to more removal of items, or simply to an increased thoughtfulness about the library's materials.

A related question asked if respondents had received requests from law enforcement for library-related information. The level of law enforcement (local, state, or federal) was left unspecified to give the respondents more leeway in their response. ${ }^{25}$ As shown below (see table 9), the majority of respondents reported no visits from

\begin{tabular}{|l|c|c|}
\hline \multicolumn{3}{|c|}{ TABLE 9} \\
Frequency of Law Enforcement Visits in \\
Academic Libraries
\end{tabular}
law enforcement $(82.52 \%)$. Approximately 14 percent reported that law enforcement visited less often than once per year. Baccalaureate colleges were significantly less likely to report any visits than research or associate colleges $\left(x^{2}(2)=15.38, P=0.0005\right)$. Only 5.6 percent of baccalaureate colleges reported any law enforcement visits, compared to 22.4 percent of research universities and 19.2 percent of associate colleges.

\section{Defining Intellectual Freedom}

In the final section, respondents were asked to define intellectual freedom. 
Recall that the ALA defines intellectual freedom as "the right of every individual to both seek and receive information from all points of view without restriction. It provides for free access to all expressions of ideas through which any and all sides of a question, cause or movement may be explored" (ALA Intellectual Freedom Q\&A, 2016, paragraph 1). About a dozen respondents quoted this ALA definition or explicitly referred to it. Others referred to the ALA Library Bill of Rights, the American Association of University Professors (AAUP) academic freedom statement, the Code of Ethics of Health Librarianship, and the U.S. Constitution.

Many respondents described intellectual freedom as the right to read, view, and write information; other verbs used included access, believe, browse, consult, consume, convey, dig, digest, discuss, disseminate, espouse, evaluate, explain, explore, express, feel, find, gather, hear, inquire, investigate, learn, listen, obtain, provide, pursue, question, receive, research, review, search, seek, share, speak, study, teach, think, understand, use, and watch. So, for example, respondents defined intellectual freedom as the freedom, the right, or the ability "to access information freely," "to investigate any subject or topic...to express an opinion on controversial issues," and "to pursue, provide, and have access to information and knowledge." In addition, many respondents added qualifiers to these statements. Eighteen administrators acknowledged that intellectual freedom may have some limitations:

- "Freedom to pursue information within the framework of fair use for copyright."

- "Freedom to read/view anything or publish anything that does not infringe the freedom, dignity, or safety of others."

- "Ability of patron to access the information they need-as long as it is not illegal-and to express themselves as they wish - and as long as it is not illegal."

- "Freedom to collect materials on all points of view provided the materials meet the standards of scholarship and are not polemical."

- "The freedom to read, write and research any areas of interest, so long as one is not impinging on the copyright or ownership [of] others, and as long as one is not participating in or promoting an activity that may harm others."

- "The ability to read, write, and speak about anything within the limits of the First Amendment."

- "The protected right to think and learn about the world with minimal restrictions (health and age restrictions can be reasonable limitations)."

- "Freedom to read or write or say anything so long as it is not seriously threatening in nature."

For these respondents, intellectual freedom comes with some boundaries. The ALA would likely support those who invoke legal limitations (such as banning child pornography or protecting copyright), but other limits suggested by the respondents above are a bit more vague or out of step with the prevalent librarian ethics. For example, "seriously threatening in nature" seems subjective and in all likelihood not a standard that would be legally defensible. Invoking "health and age restrictions" might likewise be problematic. Along these lines, one respondent said, "I would never add a book by someone who believed in a correlation between autism and vaccines or materials denying climate change." Another emphasized collecting "academically respectable materials."

The majority of respondents, however, seemed to advocate for interpretations of intellectual freedom that had few or no boundaries. They used phrases such as "unfettered access to ideas," "without censor, judgment, or encountering other barriers, such as a paywall," "without any fear of reprisal," "without limits, fear of retribution, or personally identifiable tracking," "free of interference from others," "without being monitored," "without fear of censure or negative repercussions," "regardless of con- 
tent," "without the scrutiny of others," "without being judged," "without oversight," "without restriction regardless of point of view," "without any hindrances, with a guarantee of privacy, and without persecution," "without restriction, oversight, monitoring, or need for justification," and "without external interference." These respondents were considering ways that intellectual freedom could be limited and then explicitly rejecting those limitations. Perhaps the broadest view of intellectual freedom suggested that:

Everything produced by human intellect throughout the existence of the humankind deserve [sic] to be open to all generations of mature people (over 18 years of age). They are free to decide upon how to use the information. Unobstructed access to information and the promise of strict privacy to pursue inquiry into all/ any manner of subjects without repercussion or restriction.

Another person focused on defining intellectual freedom within the context of an academic library: "the issue for me is how intellectual freedom functions within a research library setting. We acquire materials in support of high-level academic programs and the research needs of professors and students."

One respondent said intellectual freedom is "the right to read any type of information necessary for both academic and recreational purposes regardless of moral, ethical, religious or political content." Others, similarly, emphasized the accessibility of "reading material that questions assumptions and presents viewpoints that are not part of the mainstream." Another respondent said, "the freedom to access factual and opinion-based materials from a variety of viewpoints, including those which are locally or globally unpopular." For these respondents, there was a focus on divergent or unusual points of view. In addition, one respondent added, "it also includes a collection development policy that is not restrictive." Here, we see that broad collection development is part of intellectual freedom. Furthermore, respondents suggested that intellectual freedom extended beyond books, such as covering "information and learning objects," "literary or visual content," and "artistic expression." These views are in sharp contrast to some of the definitions described above, which mentioned excluding unpopular or controversial perspectives.

Importantly, a dozen of the responses indicated that privacy was a significant component of intellectual freedom - a lack of privacy or some form of monitoring would hamper intellectual freedom. For example, one said that intellectual freedom is "the ability to read or view legal materials without being monitored." Another respondent added, "I'd go out of my way to help them get the information they need. I would go out of my way to protect their privacy." Combining several of these ideas, one respondent said it is the "provision of free, accessible, confidential information in a variety of formats representing a variety of views."

\section{Discussion}

Although some respondents' definitions of intellectual freedom relied upon the standard ALA definition, most did not. Many coined their own phrases and explanations while sharing the basic meaning and significance with the ALA definition. Perhaps most interesting, however, are the number of respondents who offered definitions with caveats, interpretations of intellectual freedom that were relativistic or somewhat constrained. Some of these constraints, such as the legality of the material viewed or read, are in line with the ALA's stance. However, other limitations suggested by the respondents differ quite a bit from the ALA. One must wonder why these differences arise: Do academic library directors and deans simply view intellectual freedom differently from the way the ALA views it? Are they themselves constrained, perhaps by 
institutional (university) policy? This may well be true for those at certain private or religious schools, those at commuter or community colleges, or those whose parent institutions have extensive restrictive policies. Are academic library directors and deans unfamiliar with the ALA's stance on intellectual freedom?

This leads us to consider training in intellectual freedom at academic libraries. The majority of respondents indicated that staff training did not include intellectual freedom. The reasons for this are unclear, but, at a minimum, it means that library staff may be unprepared to explain and defend intellectual freedom within the academic library. Decisions about issues such as privacy and collection development may not be made within an intellectual freedom framework. For example, if student workers are not trained in intellectual freedom, they may not understand the reasoning behind policies meant to protect privacy; they may be willing to divulge circulation information to faculty or other students. Without an intellectual freedom foundation, library collections may not be as diverse and broad.

The relative lack of training regarding intellectual freedom is particularly surprising given that 85.4 percent of academic library deans and directors said that intellectual freedom was either "very" or "somewhat" important in their library. Thus, it seems as though academic library directors value intellectual freedom but may not explicitly address it often. This is supported by responses to another question, asking how often the respondents think about intellectual freedom in the context of their job; few thought about it often or regularly. Intellectual freedom, then, is assumed by the respondents to have an important place in academic libraries, yet this place may not be explicitly communicated. Indeed, this stance was noted in several respondents' comments. There is a danger, here, however: if library directors and deans assume that intellectual freedom is important but do not address it with their staff, it may not seem important to the staff. They may dismiss it as a minor concern, or only important in public and school libraries, or they may not think of it at all. Without explicit, frequent, and ongoing attention paid to intellectual freedom by the academic library deans and directors, it may well fall by the wayside.

Another possible interpretation from the data here is that intellectual freedom, as it is portrayed by the ALA, is not particularly important in academic libraries. The predominant focus of the ALA's Office of Intellectual Freedom has been on challenges to materials. This is also the focus of their signature annual event, Banned Books Week. Most academic library deans and directors, however, reported few to no challenges. Only four topics related to intellectual freedom (copyright, privacy, plagiarism, and academic freedom) were selected as important by over half of the respondents. Likewise, most respondents reported few to no visits from law enforcement seeking records or information. These data can suggest that intellectual freedom is not a very significant issue for academic libraries.

However, this must be reconciled with the fact that the majority of respondents said intellectual freedom was very or somewhat important in their academic libraries. Taken together, these data suggest that the usual definition and focus of intellectual freedom from the ALA are not useful or particularly apt approaches in academic libraries. There are intellectual freedom concerns in academic libraries, but they are distinctly different from those upon which the ALA focuses. This may be acceptable-after all, most challenges occur in public and school libraries. But, as implied by the deans and directors surveyed here, other aspects of intellectual freedom must be taken into account as well. Academic libraries have different intellectual freedom priorities from the ones public or school libraries have. Perhaps the ALA needs to expand its conception of intellectual freedom beyond materials challenges, to examine these other areas.

What are these priorities? This survey suggests at least four: copyright/intellectual property, plagiarism, privacy, and academic freedom. In the free response section to 
this question, respondents described additional concerns. Future research should focus upon illuminating these concerns that are specific to academic libraries, while also noting where there are similarities with public and/or school libraries. In addition, future work should probe into the thoughts of academic library deans and directors: we need a better understanding of why they think intellectual freedom is important but do not think about it often. As an initial attempt to understand intellectual freedom in academic libraries, this study opens up as many questions as it answers. Further work can begin to focus on these questions and uncover the role that intellectual freedom plays in academic libraries.

\section{Conclusion}

This project studied intellectual freedom in academic libraries through a survey of library directors and deans. With a 19.2 percent response rate from a wide variety of institutions, this research sheds light on the perspectives of academic library leaders, who consider intellectual freedom an important value in their libraries. However, these results should be interpreted with some caution, as it is not known to what extent the respondents are representative of the overall population. It is possible that the respondents may be skewed (for example, more female respondents).

Most academic library directors and deans do not offer training on intellectual freedom or spend much time explicitly thinking about it. The most important issues (related to intellectual freedom) for the respondents include copyright, plagiarism, privacy, and academic freedom. Most respondents, when asked to define intellectual freedom, either relied upon the ALA definition or replied with phrases and ideas similar in concept. However, a significant minority offered relativist, limited definitions that would be in conflict with the ALA's stance. Further work needs to be done to investigate intellectual freedom in academic libraries in depth. 


\section{Appendix A. Intellectual Freedom Principles for Academic Libraries}

\section{An Interpretation of the Library Bill of Rights}

A strong intellectual freedom perspective is critical to the development of academic library collections and services that dispassionately meet the education and research needs of a college or university community. The purpose of this statement is to outline how and where intellectual freedom principles fit into an academic library setting, thereby raising consciousness of the intellectual freedom context within which academic librarians work. The following principles should be reflected in all relevant library policy documents.

1. The general principles set forth in the Library Bill of Rights form an indispensable framework for building collections, services, and policies that serve the entire academic community.

2. The privacy of library users is and must be inviolable. Policies should be in place that maintain confidentiality of library borrowing records and of other information relating to personal use of library information and services.

3. The development of library collections in support of an institution's instruction and research programs should transcend the personal values of the selector. In the interests of research and learning, it is essential that collections contain materials representing a variety of perspectives on subjects that may be considered controversial.

4. Preservation and replacement efforts should ensure that balance in library materials is maintained and that controversial materials are not removed from the collections through theft, loss, mutilation, or normal wear and tear. There should be alertness to efforts by special interest groups to bias a collection though systematic theft or mutilation.

5. Licensing agreements should be consistent with the Library Bill of Rights, and should maximize access.

6. Open and unfiltered access to the Internet should be conveniently available to the academic community in a college or university library. Content filtering devices and content-based restrictions are a contradiction of the academic library mission to further research and learning through exposure to the broadest possible range of ideas and information. Such restrictions are a fundamental violation of intellectual freedom in academic libraries.

7. Freedom of information and of creative expression should be reflected in library exhibits and in all relevant library policy documents.

8. Library meeting rooms, research carrels, exhibit spaces, and other facilities should be available to the academic community regardless of research being pursued or subject being discussed. Any restrictions made necessary because of limited availability of space should be based on need, as reflected in library policy, rather than on content of research or discussion.

9. Whenever possible, library services should be available without charge in order to encourage inquiry. Where charges are necessary, a free or low-cost alternative (e.g., downloading to disc rather than printing) should be available when possible.

10. A service philosophy should be promoted that affords equal access to information for all in the academic community with no discrimination on the basis of race, values, gender, sexual orientation, cultural or ethnic background, physical or learning disability, economic status, religious beliefs, or views. 
11. A procedure ensuring due process should be in place to deal with requests by those within and outside the academic community for removal or addition of library resources, exhibits, or services.

12.It is recommended that this statement of principle be endorsed by appropriate institutional governing bodies, including the faculty senate or similar instrument of faculty governance.

Approved by ACRL Board of Directors: June 29, 1999.

Adopted July 12, 2000, by the ALA Council.

From a letter dated November 15, 2000, to Judith F. Krug, director, Office for Intellectual Freedom, from the American Association of University Professors:

A copy of the new ACRL/ALA statement on Intellectual Freedom Principles for Academic Libraries: An Interpretation of the 'Library Bill of Rights' was forwarded to one of our Council members and considered by the AAUP Council in its meeting on November 11, 2000.

The AAUP Council is pleased to endorse the statement, but wishes to preface that endorsement with the following language from the Joint Statement on Faculty Status of College and University Librarians, as contained in AAUP: Policy Documents and Reports, 1995 edition:

"College and university librarians share the professional concerns of faculty members. Academic freedom, for example, is indispensable to librarians, because they are trustees of knowledge with the responsibility of ensuring the availability of information and ideas, no matter how controversial, so that teachers may freely teach and students may freely learn. Moreover, as members of the academic community, librarians should have latitude in the exercise of their professional judgment within the library, a share in shaping policy within the institution, and adequate opportunities for professional development and appropriate reward."

Please convey to the members of the ACRL Board and ALA Council our concern that college and university librarians are designated the same rights afforded to other faculty in regard to intellectual freedom. 


\section{Appendix B}

Which of the following describes your institution (Carnegie classification)?

$\square \quad$ RI university

$\square \quad$ R2 university

口 R3 university

$\square \quad$ MI university

$\square \quad$ M2 university

$\square \quad$ Baccalaureate college

$\square \quad$ Associate college

$\square \quad$ Other

Not sure

Is your institution a historically black college or university (HBCU)?

$\square \quad$ Yes

$\square \quad \mathrm{No}$

$\square \quad$ Not sure

Is your library combined with a public or K-12 library?

$\square \quad$ Yes

$\square \quad \mathrm{No}$

Please indicate your age:

$\square \quad 25$ or younger

26-35

ㅁ 36-45

$\quad 46-55$

․ 56 or older

Prefer not to answer

Please indicate your gender:

$\square \quad$ Male

$\square \quad$ Female

$\square \quad$ Other/Prefer not to answer

Please indicate which of the following degrees you hold: (You may check more than one.)
$\square \quad$ MLS or equivalent
$\square \quad$ Other Master's degree
$\square \quad$ Ph.D. or equivalent
$\square \quad$ J.D.
$\square \quad$ None of the above
$\square \quad$ Other

Does your library have an intellectual freedom policy?

$\square \quad$ Yes

$\square \quad$ No

$\square \quad$ Not sure

Is intellectual freedom referred to in your collection development policy?

$\square \quad$ Yes

$\square \quad \mathrm{No}$

$\square \quad$ Not sure 
Does your library refer to or use any of these policies or statements from the American Library Association? Check all that apply.

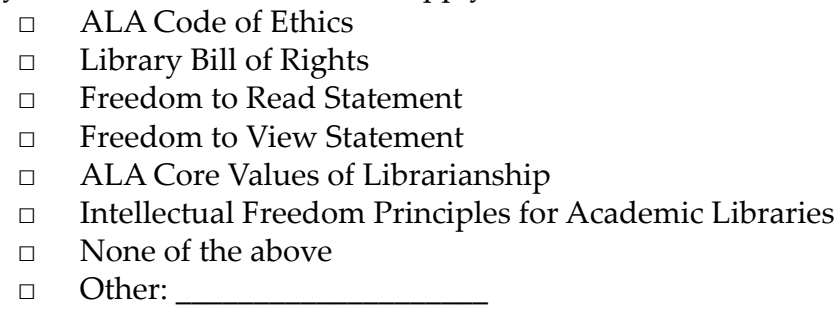

Do you provide intellectual freedom training for staff? If so, please describe it below:

How important is intellectual freedom in your library?

$\begin{array}{ll}\square & \text { Very important } \\ \square & \text { Somewhat important } \\ \square & \text { Neither important or unimportant } \\ \square & \text { Somewhat unimportant } \\ \square & \text { Very unimportant }\end{array}$

If you have any comments on the question above, please include them here.

In your role as Dean/Director, how often do you think about intellectual freedom?

$\begin{array}{ll}\square & \text { Daily } \\ \square & \text { 2-3 times a week } \\ \square & \text { Once a week } \\ \square & \text { 2-3 times a month } \\ \square & \text { Once a month } \\ \square & \text { Less than once a month } \\ \square & \text { Never }\end{array}$

What are some of the most important intellectual freedom concerns in your library? Check all that apply.

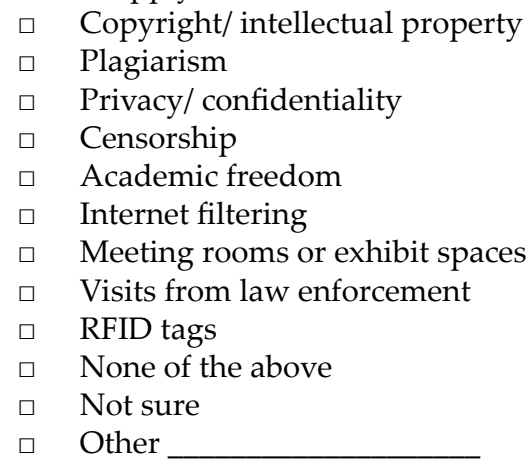

How often do you receive challenges to library materials (i.e., requests to censor something)?

$\square \quad$ Once a week

$\square \quad$ Once a month

ㅁ 2-3 times a semester 


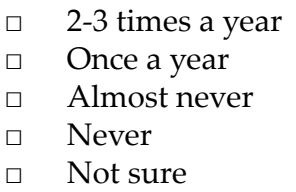

What is the library policy for handling challenges to library materials?

How often do you receive requests from law enforcement for library-related information?

$\begin{array}{ll}\square & \text { Once a week } \\ \square & \text { Once a month } \\ \square & \text { 2-3 times a semester } \\ \square & \text { 2-3 times a year } \\ \square & \text { Once a year } \\ \square & \text { Less than once a year } \\ \square & \text { Never } \\ \square & \text { Not sure }\end{array}$

How would you define intellectual freedom?

Do you have additional thoughts or comments about intellectual freedom in academic libraries? If so, please write them here.

I plan to follow this survey with a qualitative interview study. I want to interview people who frequently deal with or think about intellectual freedom, those who rarely do so, and everyone in between. All perspectives are unique and important.

All interview responses will be confidential. They will not be connected to your responses to this survey.

If you would be willing to be interviewed on this matter, please click the link below and then enter your email address. Thank you for your consideration. [Link Removed]

\section{Notes}

1. American Library Association, "Intellectual Freedom Q\&A" (2016), available online at www.ala.org/advocacy/intfreedom/censorshipfirstamendmentissues/ifcensorshipqanda [accessed 15 July 2016].

2. Ronald N. Bukoff, "Censorship and the American College Library," College E Research Libraries 56 (1995): 305-407.

3. Dave Harmeyer, "Potential Collection Development Bias: Some Evidence on a Controversial Topic in California," College \& Research Libraries 56 (1995): 101-11.

4. Joe Dahlstrom, "Intellection Freedom: An Academic Responsibility," Texas Library Journal 86 (2010): 28-29; Barbara M. Jones, Libraries, Access, and Intellectual Freedom: Developing Policies for Public and Academic Libraries (Chicago: American Library Association, 1999); Barbara M. Jones, Protecting Intellectual Freedom in Your Academic Library: Scenarios from the Front Lines (Chicago: American Library Association, 2009).

5. Jones, Libraries, Access, and Intellectual Freedom, 17.

6. American Library Association, "Intellectual Freedom Principles for Academic Libraries: An Interpretation of the Library Bill of Rights" (2000), available online at www.ala.org/Template.cfm ?Section=interpretations\&Template=/ContentManagement/ContentDisplay.cfm\&ContentID=8551 [accessed 14 July 2016].

7. Ibid.; see also Steven Herb, "Intellectual Freedom and the Academic Library: Entering the 
Next Century with Strength," College \& Research Libraries News 60 (1999): 841-43.

8. W. Lee Hisle, "Facing the New Millennium: Values for the Electronic Information Age," College E Research Libraries 59 (1998): 7.

9. Richard A. Danner and Barbara Bintliff, "Academic Freedom Issues for Academic Librarians," Legal Reference Services Quarterly 25 (2006): 14-15.

10. Jones, Protecting Intellectual Freedom; see also Shannon M. Oltmann, "Intellectual Freedom and Freedom of Speech: Three Theoretical Perspectives," Library Quarterly 86 (2016): 153-71.

11. Danner and Bintliff, "Academic Freedom Issues"; Jones, Protecting Intellectual Freedom.

12. Danner and Bintliff, "Academic Freedom Issues."

13. Charlene C. Cain, "Intellectual Freedom in Academic Libraries," Louisiana Libraries (Winter 2006): 29-30; Danner and Bintliff, "Academic Freedom Issues."

14. Jones, Protecting Intellectual Freedom, 55.

15. Danner and Bintliff, "Academic Freedom Issues."

16. Jones, Protecting Intellectual Freedom, 4; see also Jones, Libraries, Access, and Intellectual Freedom.

17. J. Douglas Archer, "Intellectual Freedom and Academic Libraries: New Challenges," Indiana Libraries 31 (2012): 13-17.

18. Dahlstrom, "Intellectual Freedom," 2010; Trina Magi, "A Content Analysis of Library Vendor Privacy Policies: Do They Meet Our Standards?" College E Research Libraries 71 (2010): 254-72; Alan Rubel and M. Zhang, "Four Facets of Privacy and Intellectual Freedom in Licensing Contracts for Electronic Journals," College \& Research Libraries 76 (2015): 427-49.

19. Jones, Protecting Intellectual Freedom.

20. Ibid.; Danner and Bintliff, "Academic Freedom Issues."

21. Jones, Protecting Intellectual Freedom, 66.

22. Jones, Protecting Intellectual Freedom, 76.

23. Richard E. Rubin, Foundations of Library and Information Science, 3rd ed. (New York: Neal Schuman Publishers, 2010), 108.

24. Rubin, Foundations of Library and Information Science, 113.

25. Libraries that receive National Security Letters (NSLs) from the Department of Homeland Security may be placed under a gag order, blocking any communication about the investigation. Other laws and policies at state and local levels may also limit communication about investigations. It was hoped that asking broadly about law enforcement visits, without asking for details, would enable library directors and deans to answer this question appropriately. 